\title{
STUDIES ON ENTOMOLOGICAL MONITORING: MOSQUITO SPECIES FREQUENCY IN RIVERINE HABITATS OF THE IGARAPAVA DAM, SOUTHERN REGION, BRAZIL
}

\author{
Rosa Maria TUBAKI(1), Regiane Maria Tironi de MENEZES(1), Rubens Pinto CARDOSO JUNIOR (2) \& Eduardo Sterlino BERGO (3)
}

\begin{abstract}
SUMMARY
Diversity of mosquito species was evaluated in different habitats before and after the Igarapava reservoir flooding in the Grande River, Southern Cerrado of Brazil. We aimed at verifying changes in these mosquito populations in consequence of the lake formation. Four habitats were selected as sampling stations: peridomiciliary habitat, pasture, "veredas" and gallery forest patch. Bimonthly collections were made with the Shannon trap and human bait, including diurnal, crepuscular and nocturnal period of mosquito activity. The Shannon Index results from the potential vectors were compared using Student $t$-test. Aedes scapularis, Anopheles darlingi and An. albitarsis senso latu seasonal abundance were described with moving average and compared using $\chi^{2}$ test. There were changes in the mosquito frequency in the habitats, except for the "veredas" that was $13 \mathrm{~km}$ away from the catchment area. The altering in mosquito species seasonal abundance suggests breeding places expansion. Diversity indexes can be used to monitor changes in mosquito vector population in environments where abrupt disturbance can alter disease transmission cycles.
\end{abstract}

KEYWORDS: Entomological monitoring; Aedes scapularis; Anopheles darlingi; Anopheles albitarsis s.l.

\section{INTRODUCTION}

It is well known that economic development activities when introducing radical changes on man-environment relationships may also disrupt disease patterns producing new areas of prevalence and outbreaks of disease. Water management systems are particularly related to this matter because they imply in a succession of ecosystem disturbances involving also parasitic and infectious diseases transmission cycles. In case of construction of dams, the number of breeding places for anophelines can increase or the contact with people can be intensified in the habitats of phlebotomine and sylvatic culicines vectors of arboviroses.

HUNTER et $a l .{ }^{12}$ propose that an infrastructure for the control of some endemic diseases can reduce or eliminate risks and if preventive measures are taken early, they will require less personnel, less equipment than after the breeding areas of disease vectors expanded, the prevalence rates of diseases have increased or the people in need of assistance augmented.

So, mosquito monitoring is considered a prerequisite to prediction of trends in mosquito abundance and an appliance in integrated pest management program. As there are crude mosquito monitoring procedures, they need uniformity and standardization to analyze data adequately on habitat changes and compose a comprehensive picture of the mosquito distribution in the studying area. Different measures shall be applied in entomological monitoring as in environmental monitoring to detect changes in the shape of vector species distribution and to add scientific rigor to characterize an environment that otherwise might be made on subjective grounds.

The first mosquito survey was possibly done in the Rio Grande basin in São Paulo in $1925^{29}$ before the construction of the Rio Grande reservoir. Other studies focusing on the anopheline species were made to verify if the reservoirs were favorable breeding places to Anopheles darlingi when malaria was endemic in São Paulo ${ }^{4,5,21}$. Afterwards, studies to know the mosquito vector species potentially involved on the transmission and epidemiology of malaria and sylvatic arboviruses were performed mainly before the construction and flooding of dams $\mathrm{s}^{2,6,9,20,26,27}$.

Although some mosquito vector species are widely spread in Brazil, little information has been added to the vector species of the Cerrado biome. With the recent built of the Igarapava Dam in Southern Region of the Cerrado biome, the importance of knowledge on the potential mosquito vectors in different habitats should increase in this region, particularly with regard to the general lack of ecological information on disease transmission potential in modified habitats. The small Igarapava dam has a reservoir with an area of $38.96 \mathrm{~km}^{2}$, so the water volume necessary to fill it was reached in one month. However, as considered by COOSEMANS \& MOUCHET ${ }^{4}$, increase of surface in small dams makes shorelines potential breeding sites for vectors. 
The aim of this paper was to compare abundance and richness of mosquitoes of medical importance in diverse habitats before and after the Igarapava reservoir flooding and to describe the changes in abundance of Aedes scapularis, an incriminated vector of Rocio arbovirus and adapted in man-altered environments ${ }^{10,25}$, Anopheles albitarsis s.l., a complex of cryptic species considered an important vector of malaria in some localities and An. darlingi, the primary vector of malaria transmission in Brazil 1,14,15,27,30,31.

\section{MATERIALS AND METHODS}

Study area. The Cerrado is a biome with an environmental heterogeneity and great extension located in the Brazilian Central plateau. Due to its great extension, diversity is found in soil types, geology, climate and vegetation. Although different vegetation types are recognized, among forest, savanna and grassland communities, the savannas are the most widespread ${ }^{29}$. The Cerrado is a vegetation complex where physiognomic forms naturally change into others. Besides that, there are other forms included among the dominant ones. The most common are the corridors of mesophytic evergreen forest occurring along rivers (gallery forests) in the savanna. The gallery forests are frequently dependent from the periodic river water oscillating because of the rainy season. The most abundant species are: "breu" (Protium heptaphylum (Aubl.) March.) , "ata brava" (Talauma ovata St. Hil) and "pau-pombo" (Tapirira guianensis Aubl.) among other species. Our study was conducted in the Igarapava and Conquista districts, at the margins of the Grande River, frontier of the Minas Gerais and the São Paulo States, Southern Cerrado. Four habitats were selected as sampling stations nearby the tributaries of the Grande River (Fig. 1) and three of these riverine sites were situated in São Paulo. In the period of 1962-1992, 75\% of the cerrado vegetation had been reduced to patches in São Paulo and the main land use categories originated from environmental changes were pastures and sugarcane cultures ${ }^{16}$. So, two of these sites are highly modified: (1) a man-made peridomiciliary habitat nearby the Santa Rita Stream (20 $\left.00^{\prime} \mathrm{S} 47^{\circ} 44^{\prime} \mathrm{W}\right)$ with a blockhouse inhabited by a farmland family and (2) a pasture nearby the Fundão Stream (20 00' S $47^{\circ} 40^{\prime}$ W). The third site was part of another ecosystem that occurs near springs or small valleys in the Cerrado biome, the hyper seasonal savannas or "veredas" and has only one arboreal element, the "buriti" (Mauritia vinifera Mart.). The soil is wet in this area during the whole year. In our study, the "veredas" site was $13 \mathrm{~km}$ distant from the Fundão Stream mouth (20 00' S 47²6’W) in São Paulo. The fourth site was a preserved gallery forest patch at the mouth of the Dourados Stream (20 00' S $47^{\circ}$ $36^{\prime}$ W) in Minas Gerais.
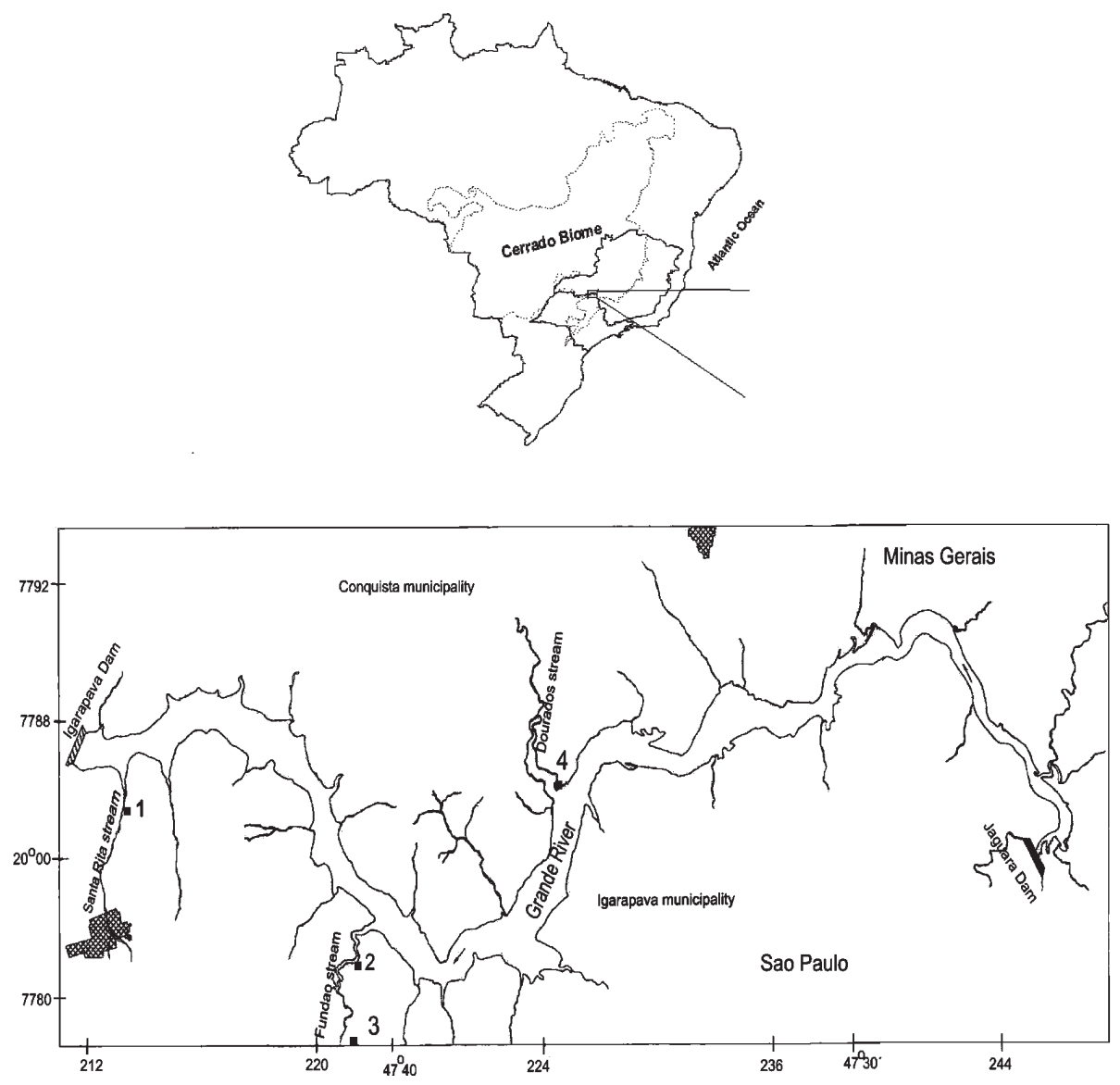

Fig. 1- Habitats nearby the tributaries of the Grande River: 1) peridomiciliary habitat, 2) pasture, 3) "veredas" and 4) gallery forest patch. 
The tropical climate is alternately humid and dry. It has two definite seasons: a rainy season (December-February) with $1200-1300 \mathrm{~mm}$ in 60 days and a dry season (June-August) with 150-200 $\mathrm{mm}$ in 10-15 days. The high altitudes are the physical factor that regulates the thermic differences in the region and the annual average temperature is $22{ }^{\circ} \mathrm{C}^{35}$. The rain data were obtained from a precipitation station at the Junqueira sugarcane mill, nearby the Fundão Stream $2 \mathrm{~km}$ away from the dam.

Mosquitoes collections. Collections were performed at the ground level simultaneously by two-men teams, one team at the Shannon trap distant $50 \mathrm{~m}$ from the other at the human bait in the studied habitats. Due to the great distance among the habitats, each one was sampled in the subsequent day. The catches occurred bimonthly including a diurnal period (one hour and 30 minutes before the crepuscular period), 30 minutes comprising the vespertine crepuscular period and a following nocturnal period (one hour and 30 minutes) of mosquito activity, from February 1997 through December 2000. The sampling periods varied around the crepuscular intervals estimated according to the Nautical Almanac ${ }^{21,22,23,24}$.

Methods of analysis. Mosquito species diversity in the habitats (peridomiciliary habitat, pasture, forest and "veredas") was compared by means of the Shannon diversity index ( $\left.H^{\prime}\right)$ and the Shannon evenness measure $(\mathrm{E})^{20}$ before and after the reservoir flooding. Student's $t$-test was used to assess differences in the mosquito diversity at the sites. Analysis was also undertaken to monitor potential vectors throughout the period and $\chi^{2}$ test was used to assess differences at their species abundance before and after the flooding phase that occurred in October 1998. A twelve-month moving average ${ }^{8}$ was applied to smooth out irregularities in the potential vector species abundances and to estimate a possible trend throughout the monitoring period. The total number of mosquitoes collected of the potential vector species An. darlingi, An. albitarsis s.l. and Ae. scapularis was correlated with the accumulated values of rainfall 15 days before the collection date. The distribution of number of mosquitoes and of rainfall were tested to normality by the Kolmogorov-Smirnov test and the Spearman coefficient $(\rho)$ to the 5\% level of significance was used to verify the correlation between the number of mosquitoes and rainfall.

\section{RESULTS}

A total of 3,969 adult mosquitoes were collected in the four habitats. The percentage compositions of Ae. scapularis (17\%) showed that this potential vector species was the most abundant followed by An. albitarsis s.l. (3\%) and An. darlingi $(9.95 \%)$. The richness by habitat of both daytime and overnight collections showed that the "veredas" comprised 39 species, while 36 species were collected in the gallery forest. Possibly because human presence was permanently in its vicinity, 32 species were collected in the peridomiciliary habitat and the pasture included 27 species (Table 1).

The Shannon index takes into account the evenness of the species abundances and allows calculating a separate measure of evenness. Mosquito diversity consists of number of species and their relative abundances. The Shannon index in the riverine habitats compared by the Students' $t$-test showed significant differences except for the "veredas", which was $13 \mathrm{~km}$ far from the flooded area. The "veredas" was almost as diverse $(t=0.25, p>0.05)$ as the peridomiciliary habitat $(t=10.92$, $\mathrm{p}<0.001)$ followed by the forest $(\mathrm{t}=2.89, \mathrm{p}<0.01)$ and the pasture $(\mathrm{t}=4.87, \mathrm{p}<0.001)$. The peridomiciliary habitat was the most modified in terms of diversity index; there was a marked decrease in number of species after the flooding phase. The ratio of observed diversity to maximum diversity was taken as a measure of evenness (E). E ranges from 0 to 1.0 and 1.0 represents a situation in which all species are equally abundant. Again the "veredas" maintained the evenness value suggesting there was not any environmental change in it $(\mathrm{E}$ before $=$ $0.792823, \mathrm{E}$ after $=0.758262)$. Evenness was strongly diminished $(\mathrm{E}$ before $=0.832184, \mathrm{E}$ after $=0.491529)$ in the peridomiciliary habitat, it decreased in the pasture $(\mathrm{E}$ before $=0.601181$, $\mathrm{E}$ after $=0.453728)$ and it slightly increased in the forest patch $(\mathrm{E}$ before $=0.685053, \mathrm{E}$ after $=$ 0.711011 ) showing a new balance in the distribution of number of mosquitoes between species after the formation of the lake.

Results of statistical tests and changes in vector species abundance before and after the flooding phase are shown in Fig. 2. The twelvemonth moving averages showed a regular decrease on the Ae. scapularis abundance in the gallery forest throughout the monitoring period and an initial increase on winter 2000. There was not variation in the Ae. scapularis curve of tendency in the peridomiciliary, pasture and "veredas" habitats (Fig. 2a). An. darlingi abundance increased throughout the period as shown by the tendency curves mainly in the pasture and the forest patch habitats. An. albitarsis s.l. abundant tendency was of regular decrease mainly in the outdoors (Fig. 2b). An. albitarsis s.l. curve was regular in the other habitats. A slight increase occurred on anophelines curves being evident in the forest and in the pasture in spring 1999 (Fig. $2 \mathrm{~b}-\mathrm{c}$ ). The flooding phase lasted almost a month and during this period, breeding places were removed as shown on larval surveys. As the distribution of the total number of mosquitoes and accumulated rainfall were not adjusted to the normal curve, the Kolmogorov-Smirnov test showed differences to the distributions $(\mathrm{p}<0.01)$. There was a slight positive and not significant correlation between the number of Ae. scapularis mosquitoes and rainfall $\left(\mathrm{r}_{\mathrm{s}}=0.21, \mathrm{p}=0.33\right)$ in the pasture and there was not correlation to the other habitats. Rainfall and $A n$. albitarsis s.l. number of mosquitoes were positively correlated but not significantly in the peridomiciliary habitat $\left(\mathrm{r}_{\mathrm{s}}=0.025, \mathrm{p}=0.907\right)$ and there was not correlation to the other habitats. Rainfall and An. darlingi number of mosquitoes were negatively correlated and significantly in the pasture $\left(r_{\mathrm{s}}=-0.39, \mathrm{p}=0.054\right)$ and there was not correlation to the other habitats. These results suggest that rainfall did not have any effect on adult mosquito catches in the studied habitats.

\section{DISCUSSION}

Ae. scapularis was the most abundant species even in the forest patch, which is a different result from that recorded by FORATTINI et al..$^{10}$ in the Southern Atlantic Forest, where Ae. serratus was more abundant than Ae. scapularis. The difference would rely on the habitat local characteristics because the cerrado forest patch was different in terms of vegetal diversity and physiomically distinctive from the Southern Atlantic patch. Even so, the most preserved habitats were the "veredas" and the forest patch. The tendency on decrease in the Ae. scapularis abundances after the flooding phase suggests that usual temporary breeding places should not be protected by the forest canopy from desiccation, as there have been made clearings, mainly near the Dourados Stream margins. Although many Ae. scapularis breeding places were covered and removed immediately at the beginning of the flooding phase, the tendency curves suggest that new breeding places might have been originated in the forest 


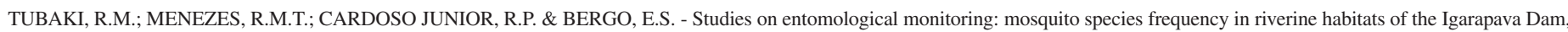
Southern Region, Brazil. Rev. Inst. Med. trop. S. Paulo, 46(4):223-229, 2004.

\section{Table 1}

Distribution of adult mosquitoes with Shannon trap and human bait in the riverine habitats before and after flooding phase in the Igarapava Dam, February 1997 to December 2000

\begin{tabular}{|c|c|c|c|c|c|c|c|c|}
\hline \multirow[t]{2}{*}{ Species/habitat } & \multicolumn{2}{|c|}{ Peridomiciliary } & \multicolumn{2}{|c|}{ Pasture } & \multicolumn{2}{|c|}{ "Veredas" } & \multicolumn{2}{|c|}{ Forest patch } \\
\hline & before & after & before & after & before & after & before & after \\
\hline Aedeomyia squamipennis & & & & & 3 & & & \\
\hline Aedes aegypti & 6 & 1 & & & & & 3 & \\
\hline Ae. albopictus & & & 1 & 1 & & & 2 & \\
\hline Ae. fluviatilis & & 3 & & & & & & \\
\hline Ae. hastatus & & & & & & & 11 & \\
\hline Ae. scapularis & 38 & 87 & 24 & 90 & 49 & 17 & 275 & 102 \\
\hline Ae. serratus & & & 4 & & 6 & 3 & 159 & \\
\hline Aedes group (serratus+ nubilus+ oligopistus) & 1 & 1 & & & & 3 & 345 & \\
\hline Ae. taeniorhynchus & 1 & 1 & & & & & 2 & \\
\hline Ae. terrens & & & & & & & 2 & \\
\hline Anopheles albitarsis s.l. & 27 & 17 & 4 & 23 & 3 & 1 & 2 & 43 \\
\hline An. argyritarsis & & & & & 4 & 2 & 1 & 3 \\
\hline An. darlingi & 12 & 9 & 12 & 194 & 4 & 5 & 6 & 153 \\
\hline An. evansae & 11 & & 2 & 2 & 2 & 5 & 15 & 18 \\
\hline An. galvaoi & 1 & 2 & 2 & 1 & 13 & 8 & 17 & 3 \\
\hline An. gilesi & & & & & 1 & & & \\
\hline An. lutzii & 1 & 7 & 1 & & 10 & 12 & 1 & \\
\hline An. oswaldoi & & & & & 1 & & & \\
\hline An. parvus & 13 & 45 & 2 & 1 & 17 & 3 & 2 & \\
\hline An. nuneztovari aff. & & & & & & & 10 & \\
\hline An. strodei & 5 & & 1 & & 19 & 8 & & 24 \\
\hline Chagasia fajardi & & & & & & 1 & & \\
\hline Coquillettidia albicosta & & & 1 & & 2 & 1 & 100 & \\
\hline Cq. chrysonotum & & & 1 & & 5 & & 23 & \\
\hline Cq. juxtamansonia & 3 & 7 & 7 & 3 & 53 & 98 & 57 & 1 \\
\hline Cq. shannoni & & & 1 & & & & & \\
\hline Cq. venezuelensis & 2 & 5 & 3 & 1 & 9 & 14 & 84 & 9 \\
\hline Culex bidens & & 1 & & 1 & & 1 & & \\
\hline$C x$. chidesteri & 13 & 8 & 1 & 4 & & 4 & 11 & 11 \\
\hline Cx. corniger & 2 & & & & & & & \\
\hline Cx. coronator & 9 & 19 & & & & 4 & 12 & 3 \\
\hline$C x$. declarator & & 502 & & 19 & & 11 & & 70 \\
\hline Cx. dolosus & 7 & 1 & & & 12 & & 6 & \\
\hline$C x$. habilitator & & 19 & & & & & & 103 \\
\hline$C x$. nigripalpus & 9 & & 5 & & 4 & & 8 & \\
\hline Cx. quinquefasciatus & & 7 & & & & & & \\
\hline$C x$. scimitar & & & & 15 & & 6 & & 29 \\
\hline Haemagogus janthinomys aff. & & 68 & 2 & & 3 & 2 & 26 & \\
\hline Hg. leucocelaenus & & & & 2 & 1 & 2 & & \\
\hline Limatus durhamii & & 1 & & & & & 7 & 6 \\
\hline Mansonia humeralis & 31 & 6 & 91 & 1 & 1 & 1 & 1 & 1 \\
\hline Ma. pseudotitillans & & 1 & & & 2 & & & \\
\hline Ma. titillans & & 8 & & & & 13 & & \\
\hline Ma. wilsoni & & 2 & & & & 5 & 2 & \\
\hline Psorophora albigenu & & & & & & & 23 & 1 \\
\hline Ps. cingulata & & & & & & 1 & & \\
\hline Ps. confinnis & & & & & & & & 1 \\
\hline Ps. discrucians & 1 & & 1 & 1 & 1 & & 1 & \\
\hline Ps. ferox & & & 4 & & & 2 & 140 & 1 \\
\hline Sabethes tridentatus & & 3 & & & & & & \\
\hline Sa. intermedius & & 2 & & & & 1 & & \\
\hline Uranotaenia ditaenionota & & & & & 11 & & & \\
\hline Ur. geometrica & & & 2 & & & 1 & & \\
\hline Ur. lowii & & & 1 & & & & & \\
\hline Ur. mathesoni & & & & & & 4 & & \\
\hline Total & 193 & 833 & 173 & 359 & 236 & 239 & 1354 & 583 \\
\hline
\end{tabular}



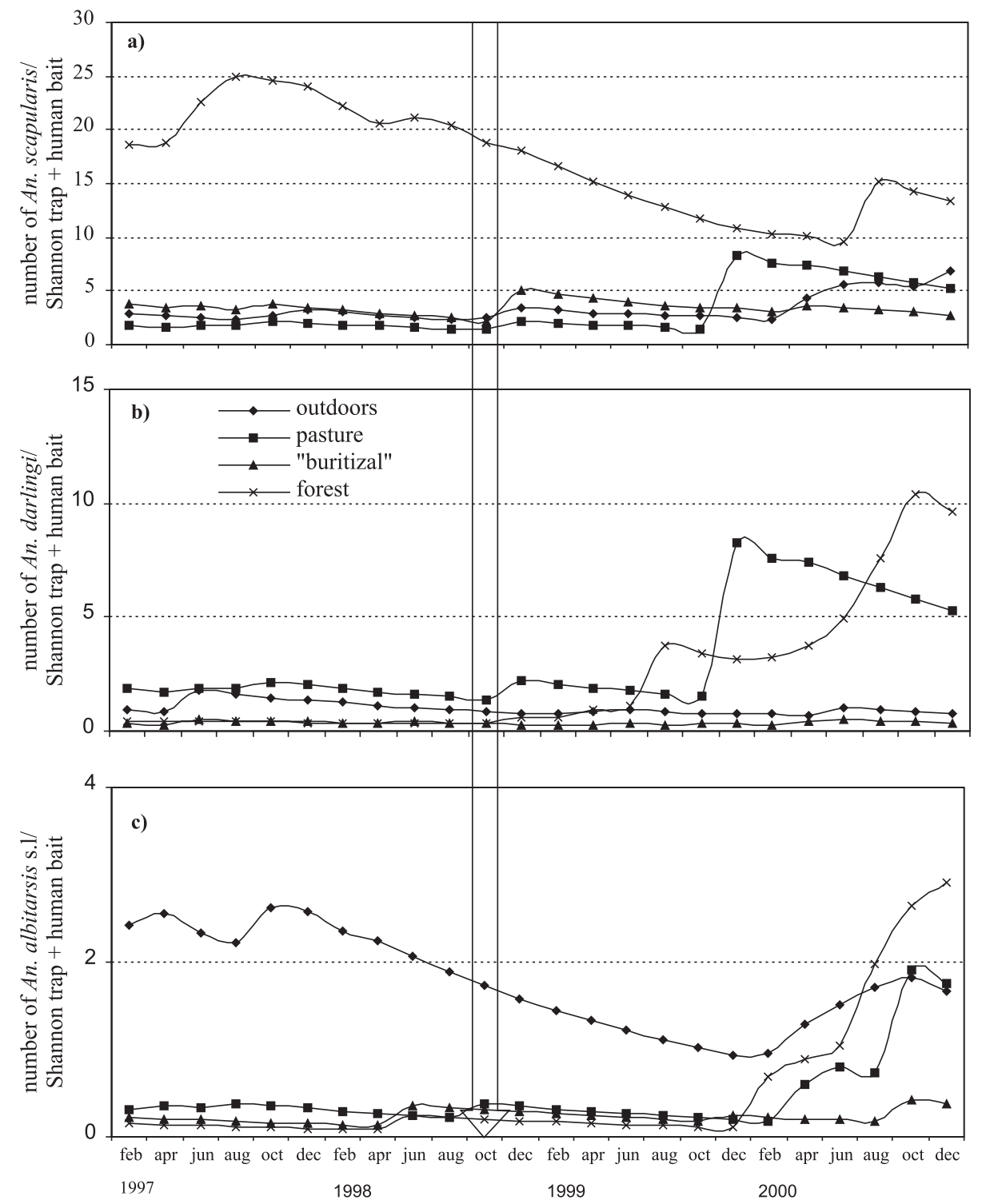

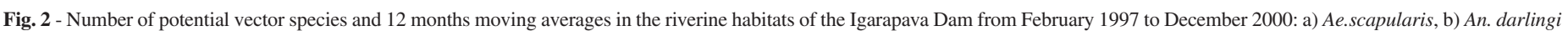

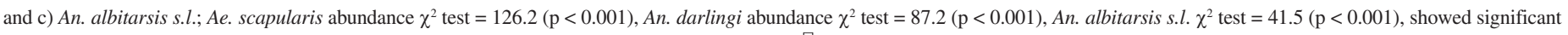
difference in species abundance before and after the built of the Igarapava Dam. Flooding phase. $\sqrt{\gamma}$

and in the pasture enough to allow the complete larval development. According to CASANOVA \& $\mathrm{PRADO}^{2}$, mortality caused by desiccation of breeding sites was the principal factor accounting for fluctuations in the number of Ae. scapularis produced in a pasture in the São Paulo State. They suggest that the combined effects of rain, air temperature, evapotranspiration and soil water balance are linked to the maintenance of breeding places. Not only rainfall but also these above mentioned and those resulting from changes in the habitats should be possibly acting in the monitoring period.

An. darlingi and An. albitarsis s.l. tendency curves showed an increase in the pasture and the forest. These results partially agrees with that previously obtained by LOURENÇO-DE-OLIVEIRA \& LUZ ${ }^{19}$ that found An. darlingi was much more abundant in anthropic environments. Although their study was made in a short period they confirmed the vector synanthropy of previous surveys made in the North Region ${ }^{13,17,18,33}$. Anopheles albitarsis s.l. is also dominant in anthropic agricultural environment in our region and as pointed out by FORATTINI et al. ${ }^{9}$ seems to alternate and to be related to flooding and emptying in rice paddies. In our study, we remind the forest patch is riparian and it is surrounded by breeding sites from the river banks and from pasture, so females from An. darlingi and An. albitarsis s.l. may possibly come from this breeding sites and feed in the forest.

The diminishing mosquito diversity highly significant $(\mathrm{p}<0.001)$ in the peridomiciliary habitat and the pasture, and significant $(\mathrm{p}<0.01)$ 


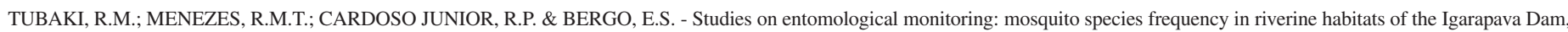
Southern Region, Brazil. Rev. Inst. Med. trop. S. Paulo, 46(4):223-229, 2004.

in the forest patch should be expected results. It is of general belief that there is a tendency of culicids diminishing diversity in ecosystems with environmental changes because breeding sites and shelters are removed. Indeed, it was not observed increase in the distribution of number of individuals among mosquito species at the period of monitoring. This result is expected as an immediate effect on the Igarapava reservoir and the basin area that were still establishing at the collections time. The "veredas" diversity index was not significant $(p>0.05)$ in terms of change in the mosquito diversity because it was far from the reservoir. The highest diversity value obtained in this habitat before and after the flooding phase might be an evidence of its preserved condition.

This study showed that diversity indexes used in environmental assessment, mainly to monitor changes in the diversity of organisms, could be applied to monitor mosquito species. Diversity indexes should be used to monitor mosquito vector species at many sites in relation to habitat type, latitude and land use and the databases generated throughout monitoring time should be used to forecast the effects of environmental change in mosquito populations. Once changes on adult mosquito species abundance are powerfully influenced by increase or removal of breeding places in the study habitats, the study of factors that regulate immature mosquito dynamics in the area is also a significant requirement.

It is important to develop adequate methods to monitor habitat changes for predictive models of mosquito population dynamics and implementing of control actions. Generally, models for impact of control methods are not available and control services rely on intuition and experience. Mosquito integrated control needs in-depth analysis, which is extremely difficult for it includes knowledge of the population dynamics of the particular mosquito species and the interrelationship with development and human activities in the area.

\section{RESUMO}

\section{Estudos em monitoramento entomológico: mudanças na freqüiência de mosquitos em habitats ripários da usina hidroelétrica de Igarapava, Sudeste do Brasil}

Avaliou-se a diversidade de mosquitos em diferentes habitats antes e depois da formação do reservatório de Igarapava no Rio Grande, Cerrado do Sudeste do Brasil, com objetivo de verificar alteração nessas populações de mosquitos. Quatro habitats foram selecionados como sítios de coleta: a) peridomicílio rural, b) pastagem, c) veredas e d) mata ciliar. Realizaram-se coletas bimestrais com isca humana e armadilha de Shannon, incluindo períodos de atividade culicídea diurna, crepuscular vespertina e noturna. Os resultados do Índice de Shannon para os potenciais vetores nos diferentes habitats foram comparados pelo teste $t$ de Student. As abundâncias sazonais de Aedes scapularis, Anopheles darlingi e Anopheles albitarsis s.l., foram descritas com a média móvel e comparadas com o teste $\chi^{2}$. Houve alteração nas freqüências dos mosquitos nos habitats, com exceção das veredas, que estavam afastadas $13 \mathrm{~km}$ da área de influência do reservatório. A modificação nas abundâncias sazonais dos potenciais vetores sugere o incremento de criadouros após a formação do reservatório. Índices de diversidade são ferramentas úteis para monitorar populações de mosquitos vetores em ambientes cujas mudanças drásticas podem alterar ciclos de transmissão de doenças transmitidas por vetores.

\section{ACKNOWLEDGMENTS}

This work was supported by the agreement Cemig-Sucen process n. $3154 / 94$.

\section{REFERENCES}

1. BRANQUINHO, M.S.; LAGOS, C.B.T.; ROCHA, R.M. et al. - Anophelines in the state of Acre, Brazil, infected with Plasmodium falciparum, $P$. vivax, the variant $P$. vivax VK247 and P. malariae. Trans. roy. Soc. trop. Med. Hyg., 87: 391-394, 1993.

2. CASANOVA, C. \& PRADO, A.P. - Key-factor analysis of immature stages of Aedes scapularis (Diptera: Culicidae) populations in southeastern Brazil. Bull. ent. Res., 92: 271-277, 2002.

3. CONSOliM, J.; LUZ, E.; PELLEGRINI, N.J.M. \& TORRES, P.B. - O Anopheles (Nyssorhynchus) darlingi Root, 1926 e a malária no lago de Itaipu, Estado do Paraná, Brasil: uma revisão de dados (Diptera: Culicidae). Arq. Biol. Tecnol., 34: 263-286, 1991.

4. COOSEMANS, M. \& MOUCHET, J. - Consequences of rural development on vectors and their control. Ann. Soc. belge Méd. trop., 70: 5-23, 1990.

5. CORREA, R.R. \& RAMOS, A.S. - Relatório das investigações entomológicas realizadas na Represa da Light e ao longo da E.F. Sorocabana, ramal Mayrink-Santos. Arq. Hig. (S. Paulo), 7: 313-333, 1942.

6. CORREA, R.R.; RAMOS, A.S. \& RACHOU, R.G. - Anofelismo e malária em algumas represas do Estado de São Paulo. Rev. bras. Malar., 18: 455-463, 1966.

7. DÉGALLIER, N.; TRAVASSOS, A.P.; HERVÉ, J-P. et al. - Modifications of arbovirus eco-epidemiology in Tucurui, Pará, Brazilian Amazônia, related to the construction of a hydroelectric dam. In: UREN, M.F.; BLOCK, J. \& MANDERSON, L.H., ed. Arbovirus research in Australia. Procedings Fifth Symposium, August 28September 1, Brisbane, CSIRO Tropical Animal Science, 1989.

8. ERRICKER, B.C. - Moving averages. In: Elementary statistics. Bristol, Hodder \& Stoughton, 1977. p. 154-168.

9. FORATTINI, O.P.; KAKITANI, I.; MASSAD, E. \& MARUCCI, D. - Studies on mosquitoes (Diptera, Culicidae) and anthropic environment. 3. Survey of adult stages at the rice irrigation system and the emergence of Anopheles albitarsis in southeastern, Brazil. Rev. Saúde públ. (S. Paulo), 27: 313-325, 1993.

10. FORATTINI, O.P.; KAKITANI, I.; MASSAD, E. \& MARUCCI, D. - Studies on mosquitoes (Diptera: Culicidae) and anthropic environment. 9. Synanthropy and epidemiological vector role of Aedes scapularis in south-eastern Brazil. Rev. Saúde publ. (S.Paulo), 29: 199-207, 1995.

11. GUIMARÃES, A.A.E.; MELLO, R.P. de; LOPES, C.M.; ALENCAR, J. \& GENTILE, C. - Prevalence of Anophelines (Diptera, Culicidae) during sunset in areas of the Itaipu Hydroelectric plant in Guaíra county, State of Paraná, Brazil. Mem. Inst. Oswaldo Cruz, 92: 745-754, 1997.

12. HUNTER, J.M.; REY, L. \& SCOTT, D. - Man-made lakes and man-made diseases. Soc. Sci. Med., 16: 1127-1145, 1982

13. KLEIN, T.A. \& LIMA, J.B. - Seasonal distribution and biting patterns of Anopheles mosquitoes in Costa Marques, Rondonia, Brazil. J. Amer. Mosq. Ass., 6: 700-707, 1990.

14. KLEIN, T.A.; LIMA, J.B.P. \& TADA, M.S. - Comparative susceptibility of anopheline mosquitoes to Plasmodium falciparum in Rondonia, Brazil. Amer. J. trop. Med. Hyg., 44: 598-603, 1991.

15. KLEIN, T.A.; LIMA, J.B.P.; TADA, M.S. \& MILLER, R. - Comparative susceptibility of anopheline mosquitoes in Rondônia, Brazil to infection by Plasmodium vivax. Amer. J. trop. Med. Hyg., 45: 463-470, 1991. 
16. KRONKA, F.J.N.; NALON, M.A. \& MATSUKUMA, C.K. - Áreas de domínio do cerrado no Estado de São Paulo. São Paulo, Secretaria do Meio Ambiente, 1998.

17. LOURENÇO-DE-OLIVEIRA, R.; GUIMARÃES, A.E.; ARLÉ, M. et al. - Anopheline species, some of their habits and relation to malaria in endemic areas of Rondônia State, Amazon Region of Brazil. Mem. Inst. Oswaldo Cruz, 84: 501-514, 1989.

18. LOURENÇO-DE-OLIVEIRA, R. - Qual a importância da hematofagia extradomiciliar do Anopheles darlingi, na Amazônia? Rev. Pat. trop., 23 (suppl.): 100-101, 1995.

19. LOURENÇO-DE-OLIVEIRA, R. \& LUZ, S.L.B. - Simian malaria at two sites in the Brazilian Amazon. II. Vertical distribution and frequency of anophelines species inside and outside the forest. Mem. Inst. Oswaldo Cruz, 91: 687-694, 1996.

20. MAGURRAN, A.E. - Ecological diversity and its measurement. Princeton, Princeton University Press, 1988.

21. MARINHA DO BRASIL - Almanaque náutico para 1997. Diretoria de hidrografia e navegação. 54. ed. Rio de Janeiro, 1997.

22. MARINHA DO BRASIL - Almanaque náutico para 1998. Diretoria de hidrografia e navegação. 55. ed. Rio de Janeiro, 1998.

23. MARINHA DO BRASIL - Almanaque náutico para 1999. Diretoria de hidrografia e navegação. 56. ed. Rio de Janeiro, 1999.

24. MARINHA DO BRASIL - Almanaque náutico para 2000. Diretoria de hidrografia e navegação. 57. ed. Rio de Janeiro, 2000.

25. MITCHELL, C.J.; FORATTINI, O. P. \& MILLER, B.R. - Vector competence experiments with Rocio virus and three mosquito species from the epidemic zone in Brazil. Rev. Saúde públ. (S. Paulo), 20: 171-177, 1986.

26. NATAL, D.; BARATA, E.A.M.F.; URBINATTI, P.R. \& BARATA, J.M.S. - Contribuição ao conhecimento da fauna de imaturos de mosquitos (Diptera: Culicidae) em área de implantação de hidrelétrica na bacia do Rio Paraná, Brasil. Rev. bras. Ent., 39: 897. 899, 1995.

27. OLIVEIRA-FERREIRA, J.; LOURENÇO-DE-OLIVEIRA, R.; TEVA, A.; DEANE, L.M \& DANIEL-RIBEIRO, C.T. - Natural malaria infection in anophelines in Rondônia State, Brazilian Amazon. Amer. J. trop. Med. Hyg., 43: 6-10, 1990.
28. RACHOU, R.G. - Relatório sobre o recenseamento realizado na represa do rio Grande Arq. Hig. (S. Paulo), 7: 243-250, 1942.

29. RIBEIRO, J.F. \& WALTER, B.M.T. - Fitofisionomias do bioma Cerrado. In: SANO S.M. \& ALMEIDA, S.P., ed. Cerrado: ambiente e flora. Planaltina, Embrapa, 1998 p. $89-168$.

30. ROSA-FREITAS, M.G.; DEANE, L.M. \& MOMEN, H. - A morphological isoenzymatic and behavioural study of ten populations of Anopheles (Nyssorhynchus) albitarsis Lynch-Arribalzaga, 1878 (Diptera: Culicidae) including from the type-localityBaradero, Argentina. Mem. Inst. Oswaldo Cruz, 85: 275-289, 1990.

31. ROSA-FREITAS, M.G.; LOURENÇO-DE-OLIVEIRA, R.; CARVALHO-PINTO, C.J.; FLORES-MENDOZA, C. \& SILVA-DO-NASCIMENTO, T.F. - Anopheline species complexes in Brazil. Current knowledge of those related to malaria transmission. Mem. Inst. Oswaldo Cruz, 93: 651-655, 1998.

32. TADEI, W.P.; MASCARENHAS, B.M. \& PODESTÁ, M.G. - Biologia de anofelinos amazônicos. VIII. Conhecimentos sobre a distribuição de espécies de Anopheles na região de Tucuruí-Marabá (Pará). Acta amaz. (Manaus), 13: 103-140, 1983.

33. TADEI, W.P.; SANTOS, J.M.M.; COSTA, W.L.S. \& SCARPASSA, V.M. - Biologia de anofelinos amazônicos. XII. Ocorrência de espécies de Anopheles, dinâmica da transmissão e controle da malária na zona urbana de Ariquemes, Rondônia. Rev. Inst. Med. trop. S. Paulo, 30: 221-251, 1988.

34. TEODORO, U.; GUILHERME, A.L.F.; LOZOVEI, A.L. et al. - Culicídeos do lago de Itaipu, no Rio Paraná, sul do Brasil. Rev. Saúde públ. (S. Paulo), 29: 6-14, 1995.

35. TROPPMAIR, H. - Regiões ecológicas do Estado de São Paulo. São Paulo, Instituto de Geografia da USP, 1975

36. VARGAS, A. \& SAVELLI, M. - Armazenamentos d' água e malária. Rev. bras. Malar., 1 (supl.): 242-263, 1949.

Received: 9 May 2003

Accepted: 10 August 2004 